\title{
A375 Melanoma Cells are Sensitized to Cisplatin-Induced Toxicity by a Synthetic Nitro-Flavone Derivative 2-(4-Nitrophenyl)-4H-Chromen-4-one Through Inhibition of PARP1
}

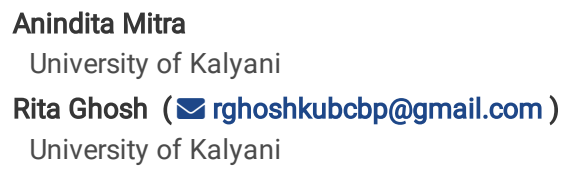

\section{Research Article}

Keywords: Cisplatin, Flavone derivative, Combination therapy, Molecular Docking, Apoptosis, Poly (ADP-ribose) polymerase 1 (PARP1).

Posted Date: June 18th, 2021

DOI: https://doi.org/10.21203/rs.3.rs-616350/v1

License: (c) (1) This work is licensed under a Creative Commons Attribution 4.0 International License. Read Full License

Version of Record: A version of this preprint was published at Molecular Biology Reports on August 3rd, 2021. See the published version at https://doi.org/10.1007/s11033-021-06600-w. 


\section{Abstract}

Background: Cisplatin has been extensively used in therapeutics for its broad-spectrum anticancer activity and frequently used for the treatment of solid tumors. However, it presents several side-effects and several cancers develop resistance. Combination therapy of cisplatin with poly (ADP-ribose) polymerase 1 (PARP1) inhibitors has been effective in increasing its efficacy at lower doses.

Methods and Results: In this work, we have shown that the nitro-flavone derivative, 2-(4-Nitrophenyl)-4H-chromen-4-one (4NCO), can improve the sensitivity of cancer cells to cisplatin through inhibition of PARP1. The effect of $4 \mathrm{NCO}$ on cisplatin toxicity was studied through combination therapy in both exponential and density inhibited A375 melanoma cells. Combination index $(\mathrm{Cl})$ was determined from isobologram analysis. The mechanism of cell killing was assessed by lactate dehydrogenase (LDH) assay. Temporal nicotinamide adenine dinucleotide (NAD $)$ assay was done to show the inhibition of PARP1. We also performed in silico molecular modeling studies to know the binding mode of 4NCO to a modeled PARP1-DNA complex containing cisplatin-crosslinked adduct. The results from both in silico and in cellulo studies confirmed that PARP1 inhibition by 4 NCO was most effective in sensitizing A375 melanoma cells to cisplatin. Isobologram analysis revealed that $4 \mathrm{NCO}$ reduced cell viability both in exponential and density inhibited A375 cells synergistically. The combination led to cell death through apoptosis.

Conclusion: The synthetic nitro-flavone derivative 4NCO effectively inhibited the important nuclear DNA repair enzyme PARP1 and therefore, could complement the DNA-damaging anticancer drug cisplatin in A375 cells and thus, could act as a potential adjuvant to cisplatin in melanoma therapy.

\section{Introduction}

Cisplatin has been widely used as an anticancer agent in the treatment of different types of cancer that includes - brain tumors, neuroblastoma, mesothelioma, head and neck cancer, lung cancer, breast cancer, ovarian cancer, cervical cancer, testicular cancer, bladder cancer, esophageal cancer, cancer of bones, muscles, soft tissue, blood, etc. Chemotherapy using cisplatin has major disadvantages as it has several dose-limiting side-effects like nephrotoxicity, neurotoxicity, nausea, ototoxicity and is also faced by problems related to the development of resistance [1][2]. Combination therapy using nontoxic doses of two or more drugs can offer a means of overcoming these problems. Functionally, cisplatin forms DNA cross-linkages creating lesions which stalls cell-division and induces apoptosis [3]. Generally, the repair enzymes are activated immediately on detection of the cisplatin-induced DNA lesions initiating repair activities [1]. Therefore, drugs inhibiting these enzymes are often used as an adjuvant to sensitize cells to cisplatin at low doses. One such important repair enzyme is poly (ADP-ribose) polymerase 1 (PARP1) [4][5]. Several PARP1 inhibitors like nicotinamide, benzamide, 3-amino benzamide (3AB), 9-phenylacridine (ACPH), NU1025, NU1088, PD128763 are often used in conjunction with cisplatin to make it effective at low doses [5]. Several flavones are also known to have PARP1 inhibitory activities [6], among them a synthetic flavone derivative is 2-(4-Nitrophenyl)-4H-chromen-4-one (4NCO). From our earlier work based on in silico studies, we have observed that 4 NCO could bind at the catalytic site of PARP1 thereby acting as a potent competitive inhibitor hindering the entry of nicotinamide adenine dinucleotide $\left(\mathrm{NAD}^{+}\right)$, the natural substrate of PARP1 [7]. 4NCO is a biologically potent flavone derivative that also possesses anti-inflammatory, anxiolytic, antioxidant, antitumor and anti-metastatic activities and also known for its tyrosine kinase, BDZ receptor, CDK2, CK2, aldose reductase and DNA binding properties [8][9][10][11][12]. In this work, we have therefore investigated the possible synergism between 4NCO and cisplatin in cancer cells. A375 melanoma cells were used for the study. Trypan blue dye-exclusion (TBE) assay was utilized for assessing the influence of $4 \mathrm{NCO}$ on cisplatin-induced cell killing in both exponential and quiescent cells. Cells at the core of solid tumors are often resistant to killing by different chemotherapeutic agents because they are in the non-dividing quiescent state, i.e. the G0 phase of the cell cycle. Such cells are proficient in potentially lethal damage repair (PLDR) [13]. The efficacy of combined treatment of cisplatin and 4NCO was therefore evaluated in density inhibited cells as well. The corresponding combination index $(\mathrm{Cl})$ was determined through isobologram analysis which is used to determine the degree of interaction between drugs when used in combination [14]. The mode of cell killing by the drugs alone and in combination was compared to understand the effect of $4 \mathrm{NCO}$ through lactate dehydrogenase (LDH) assay. Since NAD is the natural substrate of PARP1, its depletion in cells signifies PARP1 activity. The NAD ${ }^{+}$level in cells on cotreatment with $4 \mathrm{NCO}$ and cisplatin was estimated to see whether its effect on cisplatin-induced killing of cancer cells was mediated through inhibition of PARP1 activity. Finally we performed in silico molecular modeling studies to know the binding mode of 4NCO to a modeled PARP1-DNA complex containing cisplatin-crosslinked adduct.

\section{Materials \& Methods}

\subsection{Cell culture:}

Cells were maintained in exponential state of growth through routine subculture through trypsinization \{Trypsin-Ethylenediaminetetraacetic acid (EDTA) Solution 1X, HiMedia\} and sustained in minimal essential media (MEM) (HiMedia) supplemented with $10 \%$ fetal bovine serum (HiMedia) and $0.5 \%$ antibiotic antimycotic solution- $100 \mathrm{X}$ (HiMedia) at $37^{\circ} \mathrm{C}$ in a humidified $5 \% \mathrm{CO}_{2}$ atmosphere. Phosphate Buffer Saline (PBS) $\left[137 \mathrm{mM} \mathrm{NaCl}, 2.7 \mathrm{mM} \mathrm{KCl}, 8 \mathrm{mM} \mathrm{Na}{ }_{2} \mathrm{HPO}{ }_{4}\right.$, and $2 \mathrm{mM} \mathrm{KH}_{2} \mathrm{PO}_{4}, \mathrm{pH} 7.4$ ] was used for all washing and rinsing of cell. Cisplatin (Sigma-Aldrich, USA) was dissolved in $0.9 \% \mathrm{NaCl}$ and $4 \mathrm{NCO}$ was dissolved in DMSO and then diluted accordingly in MEM for treatment of cells. The DMSO concentration did not exceed $1 \%$ in any of the final treatments. For experiments involving density inhibited cells, cells were allowed to grow to confluence and then the spent medium was aspirated off from the culture dishes and replenished with fresh growth medium to maintain cells in density inhibited state for $4-5$ days before performing the experiment [5]. All the experiments were done atleast thrice and the results shown are the mean \pm SD.

\subsection{Determination of viability of exponential and confluent density inhibited cells on treatment with 4NCO and cisplatin:}

Exponentially growing A375 cells were trypsinized and plated onto $35 \mathrm{~mm}$ plates $\left(2 \times 10^{5}\right.$ cells/Petri dish) and after attachment, the cells were incubated with cisplatin $(0-10 \mu \mathrm{M})$ or $4 \mathrm{NCO}(0-60 \mu \mathrm{M})$ and treated for $24 \mathrm{hrs}$. For combination treatments, viability was determined with various doses of cisplatin (0-10 
$\mu \mathrm{M}$ ) along with $10 \mu \mathrm{M}$ or $20 \mu \mathrm{M}$ of $4 \mathrm{NCO}$ for 24 hrs treatment. Similarly, the same was determined for different doses of $4 \mathrm{NCO}(0-60 \mu \mathrm{M})$ with $0.5 \mu \mathrm{M}$ or $1 \mu \mathrm{M}$ of cisplatin for $24 \mathrm{hrs}$. For determination of viability in density inhibited confluent cultures, A375 cells were held in this state for $4-5$ days and then treated with cisplatin $(0-30 \mu \mathrm{M})$ or $4 \mathrm{NCO}(0-80 \mu \mathrm{M})$ for $24 \mathrm{hrs}$. Here also, for the combination treatments, cells were treated with various doses of cisplatin (0-30 $\mu \mathrm{M})$ along with $10 \mu \mathrm{M}$ or $20 \mu \mathrm{M}$ of $4 \mathrm{NCO}$. Similarly, the same was determined for different doses of $4 \mathrm{NCO}(0-80 \mu \mathrm{M})$ with $0.5 \mu \mathrm{M}$ or $1 \mu \mathrm{M}$ of cisplatin for 24 hrs. Viability was assayed through TBE assay. After treatment, cells were washed with PBS, trypsinized and counted in a hemocytometer after staining with $1 \%$ trypan blue (Sigma-Aldrich, USA) for 5 mins. The surviving fraction was estimated by taking the ratio of the fraction of drug-treated living cells over the living untreated control cells. The surviving fraction was then plotted against different concentration of the cisplatin or 4 NCO using Origin 8.5 software.

\subsection{Determination of Combination Index $(\mathrm{Cl})$ :}

For isobologram analysis, the inhibitory concentrations (IC) i.e. the $\mathrm{IC}_{30}, \mathrm{IC}_{50}$ and $\mathrm{IC}_{70}$ values of the cells (representing those concentrations of drugs which are required for $30 \%, 50 \%$ and $70 \%$ growth inhibition in vitro) for 24 hrs treatment with cisplatin $(0-10 \mu \mathrm{M})$ with or without co-treatment with $4 \mathrm{NCO}(10$ or $20 \mu \mathrm{M})$ was determined from the survival curves of the exponentially growing cells. Similarly, the same was determined for treatment with $4 \mathrm{NCO}(0-60 \mu \mathrm{M})$ with or without cisplatin $(0.5 \mu \mathrm{M}$ or $1 \mu \mathrm{M})$ for 24 hrs exposure for these cells. The IC values were also determined for the treatments done in density inhibited cells for the combination treatments of $4 \mathrm{NCO}$ and cisplatin from the survival curves. Origin 8.5 software was used for the determination of all the $I_{C}$ values. $I C_{30}$, IC $C_{50}$ and $I_{70}$ values of $4 \mathrm{NCO}$ and cisplatin were then marked on $\mathrm{X}$ and $\mathrm{Y}$ axes respectively and the additive effects were represented by a line which was drawn between each IC values. The combined effect of cisplatin and 4 NCO in A375 cells (both for exponential and density inhibited cells) was evaluated using the combination index (Cl). Following the classic isobologram equation as reported by Chou 2010, which is combination index (Cl) $=[(\mathrm{D}) 1 /(\mathrm{Dx}) 1]+[(\mathrm{D}) 2 /(\mathrm{Dx}) 2]$, where (D) 1 and (D)2 represent the doses of the drugs to be used in combination, and (Dx) 1 and (Dx)2 represent the dose of the same efficacy when two drugs are used alone [15]. Cl of each treatment was calculated. Any value on the area falling on the right side of each IC additive line portrays antagonistic effect and that falling on the left side depicts synergistic effect and on the line depicts additive effect or in other words, $\mathrm{Cl}<1$ is a synergistic effect; $\mathrm{Cl}=1$ is an additive effect; and $\mathrm{Cl}>1$ is an antagonistic effect [14].

\subsection{Determination of mechanism of cell killing from Lactate Dehydrogenase assay:}

A375 cells were seeded in $35 \mathrm{~mm}$ Petri dishes at a density of $2 \times 10^{5}$ cells/Petri dish and treated with $4 \mathrm{NCO}(10 \mu \mathrm{M}$ or $20 \mu \mathrm{M})$ with and without cisplatin $(0.5$ or $1 \mu \mathrm{M}$ ) for $24 \mathrm{hrs}$. The LDH activity was measured using a standard kit (Coral) as described earlier [16]. LDH was assayed in the cells in culture, from the floating dead cells and in the cellular supernatant. The floating dead cell population arises from the cells which have undergone programmed cell death mainly apoptosis, while, that in the supernatant culture medium are from the necrotic population. The LDH from the adherent cells would be from the viable cells. The LDH activity was therefore quantified for all these three different fractions in untreated and treated cells for each experiment. The floating cells were collected from the culture media by centrifugation at 2,500 rpm at $4^{\circ} \mathrm{C}$ for 5 mins. The LDH content from the pellets of the floating cells was marked as LDHp; the released extracellular LDH in the culture supernatant was from the necrotic cells, indicated as LDHe and that present in adherent cells was from the viable cells was designated as LDHi. The percent of cells that were apoptotic, necrotic or viable were determined as follows:

$\%$ Apoptosis cells $=$ LDHp $\times 100 \% /($ LDHp + LDHi + LDHe $)$

$\%$ Necrosis cells $=$ LDHe $\times 100 \% /($ LDHp + LDHi + LDHe $)$

$\%$ Viable cells $=\mathrm{LDHi} \times 100 \% /(\mathrm{LDHp}+\mathrm{LDHi}+\mathrm{LDHe})$

\subsection{Effect on cellular DNA repair by NAD ${ }^{+}$Assay:}

$2 \times 10^{5}$ exponentially growing $\mathrm{A} 375$ cells were exposed to $5 \mu \mathrm{M}$ of cisplatin with or without co-treatment with $10 \mu \mathrm{M}$ or $20 \mu \mathrm{M}$ of $4 \mathrm{NCO}$ for different time periods $(0,0.5,1,6,12,24,30$ and $36 \mathrm{hrs})$. The NAD ${ }^{+}$content in treated cells were determined as described earlier [17]. The treated cells were washed twice with ice cold PBS and acidified with $1 \mathrm{ml}$ of $0.5 \mathrm{M} \mathrm{HClO}_{4}$, which was then kept on ice for 20 mins. $900 \mu$ of the supernatant was collected and neutralized with $450 \mu \mathrm{l}$ of $1 \mathrm{M} \mathrm{KOH}, 0.33 \mathrm{M} \mathrm{K}_{2} \mathrm{HPO}_{4} / \mathrm{KH}_{2} \mathrm{PO}_{4}, \mathrm{pH} 7.5$. This was allowed to stand on ice for 20 mins before centrifugation at 10,000 rpm for $5 \mathrm{mins}$ at $4^{\circ} \mathrm{C}$. The collected supernatant $(350 \mu \mathrm{l})$ was then mixed with the reaction mixture $(310 \mu \mathrm{l})$ containing Bicine $\{(60 \mu \mathrm{l}, 1.2 \mathrm{M} \mathrm{pH} 7.8$, (HiMedia, India) $\}$, Bovine Serum Albumin $\{60 \mu \mathrm{l}, 10 \mathrm{mg} / \mathrm{ml}$ (Sigma-Aldrich, USA)\}, ethanol $(60 \mu \mathrm{l}, 6 \mathrm{M})$, EDTA $\{6 \mu \mathrm{l}, 500 \mathrm{mM}$ (HiMedia, India) \}, phenazineethosulfate $\{60 \mu \mathrm{l}, 20 \mathrm{mM}($ SigmaAldrich, USA)\}, 3-(4,5-dimethylthiazol-2-yl)-2,5-diphenyl tetrazolium bromide $\left\{60 \mu \mathrm{l}, 5 \mathrm{mM}\right.$ (Sigma-Aldrich, USA)\} and $\mathrm{H}_{2} \mathrm{O}(4 \mu \mathrm{l})$. This solution was then incubated in the dark at $30^{\circ} \mathrm{C}$ for 5 mins. Then, alcohol dehydrogenase $\{60 \mu \mathrm{l}, 1$ unit/ml, (Sigma-Aldrich, USA) $\}$ was added and again incubated at $30^{\circ} \mathrm{C}$ in the dark for 30 mins for color development. Finally, the absorbance values were taken at $570 \mathrm{~nm}$ after adding iodoacetate $\{300 \mu \mathrm{l}, 12 \mathrm{mM}(\mathrm{HiMedia}$, India) $\}$ in a HITACHI U-2910 double beam spectrophotometer. Each of the experiments was repeated thrice.

\subsection{Molecular Docking studies:}

Molecular docking provides possible insight into the binding of any ligand to its receptor. The whole human PARP1 protein (PDB ID: 4DQY, resolution: 3.25 A) was downloaded from https://www.rcsb.org/ as described earlier [7][18][19]. The bound DNA structure was removed and the protein structure was refined using the 'clean protein' tool in Discovery Studio (DS) 2.5 platform where the missing atom residues were added and waters were removed. Energy minimization of the structure was then done using the 'energy minimization' protocol of DS 2.5 using Steepest Descent and Conjugate Gradient algorithms respectively applying the CHARMm forcefield until the Root Mean Square Deviation (RMSD) reached a value of $0.001 \mathrm{kcal} / \mathrm{mol} / \AA ̊ \AA$ [7]. The stereochemistry of the energy minimized structure was checked using Ramachandran plot [20].The PDB structure of the DNA decamer containinig guanine-crosslinked adduct of cisplatin (PDB ID: 1A2E, resolution: $1.63 \AA ̊$ ) was downloaded from https://www.rcsb.org/ [19][21]. The water molecules were removed and it was also energy minimized according to the above protocol using DS 2.5. Protein-nucleic acid modeling between the PARP1 protein and the refined cisplatin-crosslinked DNA was carried out in HDOCK and further confirmed in NPDock and PatchDock servers. HDOCK follows a hybrid algorithm involving both ab initio free docking 
and template-based modeling [22]. NPDock is based on a combination of global macromolecular docking using GRAMM, scoring and clustering of bestscored structures using statistical methods and local refinement [23]. PatchDock is based on shape complementary principles including molecular shape representation, surface patch matching, filtering and scoring [24]. From the modeling results obtained from HDOCK, NPDock and PatchDock, the best model of PARP1-cisplatin adduct DNA was selected and this was compared with the available PDB of DNA bound PARP1 (PDB ID: 4DQY). The ligand, 4NCO was prepared following our earlier works [7][12]. The 3D structure of 4NCO was generated and optimized using the softwares Advanced Chemistry Development's/ ChemSketch [25] and PyMol 2.0 [26]. The 3D co-ordinates of the ligands were then refined using the 'prepare ligand' protocol of DS 2.5 platform [27]. The protocol standardizes the charges for common groups and leads to enumeration of charges in a specialized pH, generation of tautomers and isomers and also helps in calculation of 3D coordinates for each atom of the ligand molecule. Molecular docking of the ligand 4NCO was carried out with the best PARP1cisplatin crosslinked DNA model structure using PatchDock and HexDock [24][28]. In order to obtain unbiased results, in all cases, blind docking procedure was followed. The top 10 results were then scored using the 'calculate binding free energy' module of DS 2.5 to get the best docked complex having the lowest binding free energy.

\section{Results}

\subsection{Effect of combined treatment with cisplatin and 4NCO in exponentially growing cells:}

Figure 1 (A) shows the survival curve of exponentially growing A375 cells on exposure to various doses of cisplatin $(0-10 \mu \mathrm{M})$ with or without co-treatment with $4 \mathrm{NCO}(10 \mu \mathrm{M}$ or $20 \mu \mathrm{M})$ for $24 \mathrm{hrs}$. In A375 cells, for cisplatin treatment alone the $\mathrm{IC}_{50}$ value was $4.86 \pm 0.05 \mu \mathrm{M}$. Co-treatment of different doses of cisplatin with $10 \mu \mathrm{M}$ or $20 \mu \mathrm{M} 4 \mathrm{NCO}$ lowered the $\mathrm{IC}_{50}$ values to $0.74 \pm 0.05 \mu \mathrm{M}$ and $0.36 \pm 0.02 \mu \mathrm{M}$, respectively. In Fig. 1 (B) is shown the survival curve of exponentially growing $\mathrm{A} 375$ cells on treatment with different dose of $4 \mathrm{NCO}$ for $24 \mathrm{hrs}(0-60 \mu \mathrm{M})$ and on co-treatment with cisplatin $(0.5$ and $1 \mu \mathrm{M})$. The IC ${ }_{50}$ value for $4 \mathrm{NCO}$ treatment alone was $30.3 \pm 0.05 \mu \mathrm{M}$. Treatment with both doses of cisplatin potentiated the killing induced by $4 \mathrm{NCO}$. The IC ${ }_{50}$ value for $4 \mathrm{NCO}$ was reduced to $24 \pm 0.02 \mu \mathrm{M}$ and $6.9 \pm 0.02 \mu \mathrm{M}$ for $0.5 \mu \mathrm{M}$ and $1 \mu \mathrm{M}$ of cisplatin, respectively. Similar findings were obtained for the $\mathrm{IC}_{30}$ and $\mathrm{IC}_{70}$ values of cisplatin and $4 \mathrm{NCO}$, which are shown in Table 1.

Table 1

$\mathrm{IC}_{30}, \mathrm{IC}_{50}$ and $\mathrm{IC}_{70}$ values of cisplatin/4NCO in combination with $4 \mathrm{NCO} /$ cisplatin in exponentially grown and density inhibited $\mathrm{A} 375$ melan

\begin{tabular}{|c|c|c|c|c|c|c|c|c|c|c|c|c|c|}
\hline \multirow[b]{2}{*}{$\begin{array}{l}\text { 4NCO } \\
(\mu \mathrm{M})\end{array}$} & \multirow[b]{2}{*}{$\begin{array}{l}\text { Cisplatin } \\
\text { co- } \\
\text { treatment } \\
(\mu \mathrm{M})\end{array}$} & \multicolumn{6}{|c|}{ Exponentially growing cells } & \multicolumn{6}{|c|}{ Density inhibited cells } \\
\hline & & $\begin{array}{l}\% \\
\text { inhibition }\end{array}$ & $\begin{array}{l}\text { IC } \\
4 \mathrm{NCO} \\
(\mu \mathrm{M})\end{array}$ & $\begin{array}{l}\text { Cisplatin } \\
(\mu \mathrm{M})\end{array}$ & $\begin{array}{l}4 \mathrm{NCO} \text { co- } \\
\text { treatment } \\
(\mu \mathrm{M})\end{array}$ & $\begin{array}{l}\% \\
\text { inhibition }\end{array}$ & $\begin{array}{l}\text { IC } \\
\text { Cisplatin } \\
(\mu \mathrm{M})\end{array}$ & $\begin{array}{l}4 \mathrm{NCO} \\
(\mu \mathrm{M})\end{array}$ & $\begin{array}{l}\text { Cisplatin } \\
\text { co- } \\
\text { treatment } \\
(\mu \mathrm{M})\end{array}$ & $\begin{array}{l}\% \\
\text { inhibition }\end{array}$ & $\begin{array}{l}\text { IC } \\
4 \mathrm{NCO} \\
(\mu \mathrm{M})\end{array}$ & $\begin{array}{l}\text { Cisplatin } \\
(\mu \mathrm{M})\end{array}$ & $\begin{array}{l}\text { 4NCC } \\
\text { treati } \\
(\mu \mathrm{M})\end{array}$ \\
\hline \multirow[t]{9}{*}{$0-60$} & \multirow[t]{3}{*}{0} & 30 & 24.6 & $0-10$ & 0 & 30 & 2.2 & $0-80$ & 0 & 30 & 52.76 & $0-30$ & 0 \\
\hline & & 50 & 30.3 & & & 50 & 4.86 & & & 50 & 67 & & \\
\hline & & 70 & 56 & & & 70 & 7.73 & & & 70 & 81.76 & & \\
\hline & \multirow[t]{3}{*}{0.5} & 30 & 17 & & 10 & 30 & 0.4 & & 0.5 & 30 & 26.6 & & 10 \\
\hline & & 50 & 24 & & & 50 & 0.74 & & & 50 & 50.48 & & \\
\hline & & 70 & 33.2 & & & 70 & 1.66 & & & 70 & 63 & & \\
\hline & \multirow[t]{3}{*}{1} & 30 & 3.5 & & 20 & 30 & 0.2 & & 1 & 30 & 18.12 & & 20 \\
\hline & & 50 & 6.9 & & & 50 & 0.36 & & & 50 & 31.72 & & \\
\hline & & 70 & 12 & & & 70 & 0.64 & & & 70 & 51 & & \\
\hline
\end{tabular}

\subsection{Effect of combined treatment with cisplatin and 4NCO in density inhibited cells:}

Figure 1 (C) shows the survival curves of density inhibited A375 cells on exposure to cisplatin $(0-30 \mu \mathrm{M})$ treatment and on co-treatment with $4 \mathrm{NCO}(10 \mu \mathrm{M}$ or $20 \mu \mathrm{M}$ ) for $24 \mathrm{hrs}$. The $\mathrm{IC}_{50}$ value for cisplatin was $18.5 \pm 0.04 \mu \mathrm{M}$. Co-treatment with $4 \mathrm{NCO}$ caused reduction in the $\mathrm{IC}_{50}$ value of cisplatin to $11.68 \pm 0.04 \mu \mathrm{M}$ and $7.58 \pm 0.09 \mu \mathrm{M}$ for $10 \mu \mathrm{M}$ and $20 \mu \mathrm{M} 4 \mathrm{NCO}$, respectively. Similar reductions were observed for $\mathrm{IC}_{30}$ and $\mathrm{IC}_{70}$ values of cisplatin which are denoted in Table 1. Figure 1 (D) shows the effect of treatment with different doses of $4 \mathrm{NCO}(0-80 \mu \mathrm{M})$ alone and also in combination with cisplatin $(0.5 \mu \mathrm{M}$ or $1 \mu \mathrm{M})$ for $24 \mathrm{hrs}$ in density inhibited $\mathrm{A} 375$ cells. The $\mathrm{IC}_{50}$ value of $4 \mathrm{NCO}$ was $67 \pm 0.02 \mu \mathrm{M}$. Co-treatment with cisplatin reduced the IC $\mathrm{IO}_{50}$ value of $4 \mathrm{NCO}$ to $50.48 \pm 0.01$ $\mu \mathrm{M}$ and $31.72 \pm 0.01 \mu \mathrm{M}$ for $0.5 \mu \mathrm{M}$ and $1 \mu \mathrm{M}$ of cisplatin, respectively. Similar reductions in the $\mathrm{IC}_{30}$ and $\mathrm{IC}_{70}$ values of $4 \mathrm{NCO}$ observed are represented in Table 1.

\subsection{Determination of Combination Index:}

In order to determine, whether the co-treatment with these set of non-toxic doses of 4NCO and cisplatin are additive, antagonistic or synergistic in cases of exponentially growing and also for density inhibited $\mathrm{A} 375$ cells, the $\mathrm{Cl}$ values were determined and isobolographs were constructed $\{\mathrm{figure} 2(\mathrm{~A})$ and $(\mathrm{B})\}$ where

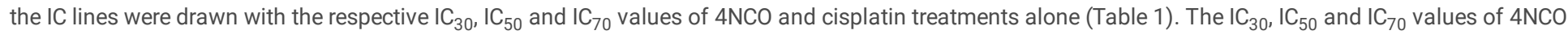
and cisplatin treatments in combinations with each other were then pointed on the graphs. The $\mathrm{Cl}$ index values have been tabulated in Table 2 . The $\mathrm{Cl}$ values, which were found to be $<1$ and the isobolographs \{figure $2(A)$ and (B) \} clearly indicated that the combinations of $4 \mathrm{NCO}$ and cisplatin in both exponentially 
grown and density inhibited A375 cells were synergistic in nature and 4NCO could potentiate cisplatin induced cell killing in these cells at these set of nontoxic doses.

Table 2

$\mathrm{Cl}$ index values of the combinations of $4 \mathrm{NCO}$ and cisplatin in $\mathrm{A} 375$ melanoma cells

\begin{tabular}{|c|c|c|c|c|c|c|c|c|}
\hline \multirow[b]{2}{*}{$\begin{array}{l}\text { Combination } \\
\text { index (CI) }\end{array}$} & \multicolumn{4}{|c|}{ Exponentially grown $\mathrm{A} 375$ cells } & \multicolumn{4}{|c|}{ Density inhibited A375 cells } \\
\hline & $\begin{array}{l}\text { Cisplatin + } 10 \\
\mu \mathrm{M} 4 \mathrm{NCO}\end{array}$ & $\begin{array}{l}\text { Cisplatin + } 20 \\
\mu \mathrm{M} 4 \mathrm{NCO}\end{array}$ & $\begin{array}{l}4 \mathrm{NCO}+0.5 \\
\mu \mathrm{M} \text { Cisplatin }\end{array}$ & $\begin{array}{l}\text { 4NCO+1 } 1 \mu \mathrm{M} \\
\text { Cisplatin }\end{array}$ & $\begin{array}{l}\text { Cisplatin + } 10 \\
\mu \mathrm{M} 4 \mathrm{NCO}\end{array}$ & $\begin{array}{l}\text { Cisplatin + } 20 \\
\mu \mathrm{M} 4 \mathrm{NCO}\end{array}$ & $\begin{array}{l}4 \mathrm{NCO}+0.5 \\
\mu \mathrm{M} \text { Cisplatin }\end{array}$ & $\begin{array}{l}4 \mathrm{NCO}+1 \mu \mathrm{M} \\
\text { Cisplatin }\end{array}$ \\
\hline 30 & 0.59 & 0.9 & 0.92 & 0.59 & 0.72 & 0.55 & 0.53 & 0.35 \\
\hline 50 & 0.48 & 0.73 & 0.89 & 0.44 & 0.78 & 0.71 & 0.78 & 0.53 \\
\hline 70 & 0.39 & 0.44 & 0.65 & 0.34 & 0.75 & 0.73 & 0.94 & 0.66 \\
\hline
\end{tabular}

\subsection{Lactate Dehydrogenase assay:}

Figure 3 shows the results of LDH assay in case of both cisplatin $(0.5 \mu \mathrm{M}$ or $1 \mu \mathrm{M})$ and $4 \mathrm{NCO}(10 \mu \mathrm{M}$ or $20 \mu \mathrm{M})$ alone and in combinations. Treatment of cells with cisplatin at doses $0.5 \mu \mathrm{M}$ and $1 \mu \mathrm{M}$ for $24 \mathrm{hrs}$ exhibited limited cell killing with few apoptotic and necrotic cells. Similar results were obtained on treatment with $4 \mathrm{NCO}(10 \mu \mathrm{M}$ and $20 \mu \mathrm{M}, 24 \mathrm{hrs})$. This corroborated the observation that these doses selected were individually non-toxic in nature. Cotreatment with $4 \mathrm{NCO}$ and cisplatin sensitized cell killing, where the relative fraction of apoptotic cells was significantly enhanced. There was a small increase in necrotic cells that was insignificant.

\subsection{Assay of $\mathrm{NAD}^{+}$level in cells:}

Figure 4 (alongwith the inset) shows the effect of cisplatin $(5 \mu \mathrm{M})$ alone or on co-treatment with $3 \mathrm{AB}(1 \mathrm{mM})$ or $4 \mathrm{NCO}(10$ or $20 \mu \mathrm{M})$ on the intracellular NAD ${ }^{+}$ activity at different time periods after the treatment in $A 375$ cells. Exposure of $A 375$ cells to $5 \mu \mathrm{M}$ cisplatin alone resulted in depletion of intracellular NAD ${ }^{+}$ level in a time dependent manner. The presence of both, $10 \mu \mathrm{M}$ as well as, $20 \mu \mathrm{M} 4 \mathrm{NCO}$ prevented this NAD depletion in the cells. $3 A B$ was used as a positive control, as a PARP1 inhibitor. It can be seen that both doses of $4 \mathrm{NCO}$ was much more effective in preventing the depletion of NAD in the cells at a considerable lower doses compared to $3 \mathrm{AB}$.

\subsection{In silico analysis of the mode of binding of the combination of cisplatin and 4NCO:}

Figure 5 (A) shows the best modeled structure of cisplatin-adduct DNA with PARP1 as obtained from the modeling servers. Here, the DNA decamer containing the cisplatin adduct is found to bind to the DNA binding domain of the protein. The superimposed structure of free PARP1 and docked PARP1 is shown in Fig. 5 (B) which depicts the changes induced after cisplatin-crosslinked DNA binding. Figure 5 (C) shows the blind-docking result of 4NCO with PARP1 complexed with the DNA containing the cisplatin adduct. It is seen that even after cisplatin-crosslinked DNA induced changes to the protein, 4NCO still binds to the nicotinamide binding site of PARP1. The binding free energy of the docked complex was found to be $-31.29632 \mathrm{kcal} / \mathrm{mol}$. Amino acid residues within 5 Å range of 4NCO were found to be Trp861, His862, Gly863, Ser864, Leu877, Arg878, lle879, Ala880, Tyr889, Gly894, lle895, Tyr896, Phe897, Ala898, Lys903, Ser904, Tyr907 and Glu988. It is also forming hydrogen bonding and hydrophobic interactions with the amino acid residues His862, Gly863, Arg878, Ala880, Tyr889, lle895, Tyr896, Ala 898 and Tyr907 ffigure 5 (D)\}.

\section{Discussion}

Two findings led to the use of PARP1 inhibitors as an adjuvant to cisplatin chemotherapy. First, it was found that cells with elevated activity of DNA repair enzymes are resistant to cisplatin while, cells with decreased DNA repair capacity, such as fibroblasts from patients with xeroderma pigmentosum are more sensitive to the drug, suggesting the importance of DNA repair inhibition [3]. An early response of DNA repair signals involves activation of PARP1 on sensing DNA damage and binding to it via its DNA binding domain for initiating repair activities.

The need for high doses and long-term administration, limits the use of cisplatin in chemotherapy. Also, resistance to the drug due to change in cellular uptake, efflux of the drug, increased biotransformation, detoxification in liver is observed in many cases [1]. PARP1 inhibitors have been effective as adjuvants in therapy of cancer but they can also be useful as preventive agents [29][30]. They also operate in some inflammatory diseases that increase the chance of development of cancer [31]. PARP1 activity is stimulated in cells by DNA breaks induced by cisplatin. PARP1 inhibitors like AG014699, Olaparib, Iniparib, Veliparib and MK4827 have been used in conjunction with cisplatin [32][33]. ACPH, a potential anticancer agent with PARP1 inhibitory properties have been shown to potentiate the killing by cisplatin to make it effective at lower doses [5]. We have seen earlier that $4 \mathrm{NCO}$ can bind to the NAD ${ }^{+}$binding pocket of PARP1 enzyme to act as its inhibitor [7]. 4NCO exhibited limited toxicity in normal cells, but was effective in inducing killing in cancer cell lines and was most found to be most effective in A375 melanoma cells as obtained from our earlier findings [34]. Therefore, the effect of combined treatment of $4 \mathrm{NCO}$ with cisplatin was tested in A375 melanoma cells. The use of drug combinations to show that they are significantly better than single agents is of particular interest. When two or more drugs that have overtly similar effects or complement each other are given together, their effects are often greatly enhanced. Our earlier result showed that the $\mathrm{IC}_{50}$ value of cisplatin treatment was reduced by 2 fold with ACPH in A375 cells [5]. Olaparib, another PARP1 inhibitor decreased the $\mathrm{IC}_{50}$ value of cisplatin by $\sim 5$ fold in A375 cells [35]. For combined treatment with cisplatin and $4 \mathrm{NCO}$ in $\mathrm{A} 375$ cells, the fold reduction IC ${ }_{50}$ was found to be $\sim 12$ fold at some concentrations chosen for the study, which indicated that 4 NCO was much more productive in potentiating the sensitivity to cisplatin-induced killing. Melanoma cells with enhanced DNA repair activities often can grow in presence of cisplatin [35]. They are found to exhibit unusual DNA repair activity; DNA polymerase zeta responsible for translesion synthesis is found to be enhanced in melanomas, which possibly accounts for the 
aggressiveness of such tumors [36][37][38]. PARP1 inhibitors can be used effectively as adjuvants to DNA damaging anticancer drugs in tumors with altered DNA repair activities [39]. Our finding showed 4 NCO to be a very effective combination with cisplatin in A375 melanoma cell line.

When the combined effect of two agents is greater than that predicted by their individual potencies, the combination is said to be synergistic. A synergistic interaction allows the use of lower doses of the combination constituent, a situation that may reduce adverse reactions. Isobologram analysis was performed to assess whether the cytotoxic effect was synergistic in nature. This analysis provides a $\mathrm{Cl}$ value, which is a quantitative measure of the degree of drug interaction between two or more agents. $\mathrm{A} \mathrm{Cl}<1.0,=1.0$, and $>1.0$ indicate synergism, additive effect and antagonism, respectively. From evaluation of the $\mathrm{Cl}_{30}, \mathrm{Cl}_{50}$ and $\mathrm{Cl}_{70}$ values of the combination treatments with $4 \mathrm{NCO}$ and cisplatin revealed that in all cases the $\mathrm{Cl}$ values were found to be $<1.0$ (Table 2 ). This unveiled the efficaciousness of co-treatment of $4 \mathrm{NCO}$ with cisplatin, which acted in synergy.

Cisplatin is a platinum coordination compound that interacts with DNA to induce both intra- and inter-strand DNA crosslinks between purines to result in DNA damage. It has been used in the therapy of different types of cancer [3]. Cisplatin is often used in the treatment of solid tumors [40]. Cells at the core of solid tumors are often refractory to the therapeutic agents as they often contain hypoxic non-dividing cells. Such quiescent cells are proficient in DNA repair through potential lethal damage repair (PLDR). Density inhibited cells are arrested in G0/G1 phase [5]. The DNA damaging action of cisplatin also occurs through metal induced free radicals that lead to cell killing through oxidative damage [41]. In order to test for the efficacy of 4NCO in solid tumors, density inhibited plateau phase cells were used as model system. Due to the involvement of PARP1 in PLDR process, inhibitors of PARP1 are effective to potentiate killing in such cells. PARP1 inhibitors like 3AB, PD128763, NU1025, AG14361 have been shown to inhibit PLDR activity in Chinese hamster V79 and CHO cells [42]. The acridine derivative ACPH which could act as a PARP1 inhibitor was also effective in sensitizing density inhibited cells to killing [5]. Isobologram analysis of cotreatment of $4 \mathrm{NCO}$ and cisplatin in density inhibited $\mathrm{A} 375$ cells also revealed the synergistic action of the combination; the findings indicated its possible efficacy in treatment of solid tumors. Combination of cisplatin and $4 \mathrm{NCO}$ could reduce the $\mathrm{IC}_{50}$ value by $\sim 5$ fold in the density inhibited $\mathrm{A} 375$ cells.

Cisplatin induces apoptotic death in cells through mitochondria and TRAIL-mediated pathways [43]. Suppression of apoptosis can lead to cisplatin resistance in cells [44]. We found that there was a significant increase in apoptosis in $4 \mathrm{NCO}$ and cisplatin co-treated cells when non-toxic doses of the individual agents were used for the treatment (Fig. 3). PARP1 activation depletes the NAD content in cells as PARP1 utilizes NAD ${ }^{+}$as its substrate for synthesis of PAR polymers. Cisplatin treatment resulted in a time-dependent depletion of intracellular NAD ${ }^{+}$in cells that were completely inhibited when $4 \mathrm{NCO}$ was used for cotreatment with cisplatin. Increment of the level of PARP1 substrate - NAD ${ }^{+}$with time indicated inhibition of PARP1 in A375 cells. This effect was much higher when compared to the established PARP1 inhibitor 3AB. 4NCO inhibited PARP1 at much lower doses than 3AB (Fig. 4). This conclusively demonstrated the PARP1 inhibitory action of $4 \mathrm{NCO}$ in the combined treatment.

In order to further confirm our findings we carried out molecular modeling studies with cisplatin-crosslinked DNA bound to PARP1 with 4NCO. The PDB structure of cisplatin-crosslinked DNA bound to PARP1 was unavailable, so we built a model for the same. It can be seen from the best modeled structure that PARP1 binds to the cisplatin adduct containing DNA through its DNA binding domain (spanning residues 1 to 353 ) as can be shown in Fig. 5 (A). Figure 5 (B) depicts the changes induced in PARP1 on binding to the cisplatin-induced damaged DNA since different forms of DNA damage leads to different kinks and angular changes in the backbone of the DNA inducing conformational changes in a DNA binding protein to accommodate it accordingly. This structure was used as a receptor for blind docking of $4 \mathrm{NCO}$. The best scored docked complex having the lowest binding free energy showed that $4 \mathrm{NCO}$ binds to the substrate binding site or the nicotinamide binding site, which are shown in Fig. 5(C) and (D). The binding free energy of the docked complex was found to be $-31.29632 \mathrm{kcal} / \mathrm{mol}$, thus, indicating this binding to be a thermodynamically favorable process. Our previous report showed that the binding free energy of the interaction between $4 \mathrm{NCO}$ and the free PARP1 protein was $-29.61673 \mathrm{kcal} / \mathrm{mol}$ [7]. Therefore, the binding free energy values were comparable, which further confirmed the feasibility of the methods followed. Interactions with the amino acid residues His862, Gly863, Tyr889, Tyr896, Lys903, Ser904, Tyr907 and Glu988 are very important for binding of PARP1 to NAD ${ }^{+}$[4]. As shown earlier, 4NCO could interact with free PARP1 at all these residues and prevented the binding of $\mathrm{NAD}^{+}$to PARP1 at the substrate binding site to act as its inhibitor [7]. Our present findings show that the same residues are also present for the interaction of 4NCO with PARP1 even after the changes induced in its structure after binding cisplatin-crosslinked DNA. Therefore, we can conclude that 4NCO can also effectively inhibit PARP1 that has already bound to DNA with cisplatin-adduct. The binding of 4 NCO at the NAD ${ }^{+}$binding catalytic domain of PARP1 ensured that $4 \mathrm{NCO}$ could still inhibit repair at the cisplatin-adduct site even after repair activity was initiated. This highlighted the effectiveness of $4 \mathrm{NCO}$ and also corroborated the findings from our experimental observations.

Our current findings conclusively proved that $4 \mathrm{NCO}$ could inhibit PARP1 to act as an effective adjuvant with cisplatin in A375 melanoma cells. The combination therapy induced synergistic cytotoxicity in the melanoma cells at non-toxic doses of the individual agents, both in exponential growing and density inhibited state by inducing apoptotic death. The efficacy of 4NCO was also heightened as it can also inhibit PARP1 that has already bound to the damaged DNA. Our present findings could justify the effectiveness of 4 NCO in A375 melanoma cells as a potential drug candidate acting as a chemotherapeutic adjuvant to cisplatin.

\section{Declarations}

\section{Acknowledgements:}

The authors are grateful to Prof. S. Ghosh, Department of Chemistry, Jadavpur University for providing authentic samples of 4 NCO for the work. The author, Anindita Mitra, acknowledges fellowship from Department of Science and Technology (DST-INSPIRE Grant: DST/INSPIRE Fellowship/2015/IF150061), Govt. of India. The authors also acknowledge the infrastructural facility at Department of Biotechnology (DBT) sponsored Bioinformatics Infrastructure Facility (BIF Centre), University of Kalyani for the work.

Funding: 
Department of Science \& Technology - Promotion of University Research and Scientific Excellence II (DST-PURSE II), Govt. of India and University Grants Commission: Special Assistance Programme Departmental Research Support II (UGC-SAP DRS II), Govt. of India.

\section{Conflicts of interest:}

There are no conflicts of interest.

\section{Availability of data and material:}

Data will be made available on request.

\section{Code availability:}

Not Applicable

\section{Ethics approval:}

Not Applicable; Studies were on cultured cells.

\section{Consent to participate}

Not Applicable

\section{Consent for Publication}

Yes

\section{References}

References:

1. Dasari S, Bernard Tchounwou P (2014) Cisplatin in cancer therapy: Molecular mechanisms of action. Eur J Pharmacol 0:364-378. https://doi.org/10.1016/j.ejphar.2014.07.025

2. Aldossary SA (2019) Review on pharmacology of cisplatin: Clinical use, toxicity and mechanism of resistance of cisplatin. Biomed Pharmacol J 12:7-15. https://doi.org/10.13005/bpj/1608

3. Basu A, Krishnamurthy S (2010) Cellular responses to cisplatin-induced DNA damage. J Nucleic Acids 2010:. https://doi.org/10.4061/2010/201367

4. Karmakar S, Manna D, Ghosh S, Hansda S, Mitra A, Bagchi A, Ghosh R (2017) 9-Phenyl Acridine: A Possible Poly (ADP-ribose) Polymerase-1 Inhibitor. J Chem Pharm Res 9:188-200

5. Karmakar S, Ghosh R (2018) Synergistic action of cisplatin and 9-phenyl acridine in A375 cells. Indian J Biochem Biophys 55:173-182

6. Geraets L, Moonen HJ, Brauers K, Wouters EF, Bast A, Hageman GJ (2007) Dietary flavones and flavonoles are inhibitors of poly(ADP-ribose)polymerase-1 in pulmonary epithelial cells. J Nutr 137:2190-2195. https://doi.org/10.1093/jn/137.10.2190

7. Mitra A, Biswas R, Bagchi A, Ghosh R (2019) Insight into the binding of a synthetic nitro-flavone derivative with human poly (ADP-ribose) polymerase 1. Int J Biol Macromol 141:444-459. https://doi.org/10.1016/j.ijbiomac.2019.08.242

8. Cushman M, Nagarathnam D, Burg DL, Geahlen RL (1991) Synthesis and Protein-Tyrosine Kinase Inhibitory Activities of Flavonoid Analogues. J Med Chem 34:798-806. https://doi.org/10.1021/jm00106a047

9. Sekhar PN, Kishor PBK, Zubaidha PK, Hashmi AM, Kadam TA, Anandareddy L, Maeyer M, De, Kumar KP, Bhaskar BV, Munichandrababu T, Jayasree G, Narayana PVBS, Gyananath G (2011) Experimental validation and docking studies of flavone derivatives on aldose reductase involved in diabetic retinopathy, neuropathy, and nephropathy. Med Chem Res 20:930-945. https://doi.org/10.1007/s00044-010-9412-4

10. Nakanishi I, Murata K, Nagata N, Kurono M, Kinoshita T, Yasue M, Miyazaki T, Takei Y, Nakamura S, Sakurai A, Iwamoto N, Nishiwaki K, Nakaniwa T, Sekiguchi Y, Hirasawa A, Tsujimoto G, Kitaura K (2015) Identification of protein kinase CK2 inhibitors using solvent dipole ordering virtual screening. Eur J Med Chem 96:396-404. https://doi.org/10.1016/j.ejmech.2015.04.032

11. Wagal OS, Joshi AJ, Joshi UJ, Bhojwani HR, Begwani KV, Dawne HA, Gude RP, Sathaye SSKD (2021) Studies in molecular modeling, in-vitro CDK2 inhibition and antimetastatic activity of some synthetic flavones. Front Biosci (Landmark Ed) 26:664-681

12. Mitra A, Saikh F, Das J, Ghosh S, Ghosh R (2018) Studies on the interaction of a synthetic nitro-flavone derivative with DNA: A multi-spectroscopic and molecular docking approach. Spectrochim Acta - Part A Mol Biomol Spectrosc 203:357-369. https://doi.org/10.1016/j.saa.2018.05.073

13. Shin-Ichiro Masunaga, Ono K, Abe M (1992) Potentially Lethal Damage Repair by Quiscent cells in murine solid tumors. Int J Radiat Oncol 22:973-978

14. Huang RY, Pei L, Liu Q, Chen S, Dou H, Shu G, Yuan ZX, Lin J, Peng G, Zhang W, Fu H (2019) Isobologram analysis: A comprehensive review of methodology and current research. Front Pharmacol 10:1-12. https://doi.org/10.3389/fphar.2019.01222

15. Chou TC (2010) Drug combination studies and their synergy quantification using the chou-talalay method. Cancer Res 70:440-446. https://doi.org/10.1158/0008-5472.CAN-09-1947

16. Manna D, Bhuyan R, Saikh F, Ghosh S, Basak J, Ghosh R (2018) Novel 1,4-dihydropyridine induces apoptosis in human cancer cells through overexpression of Sirtuin1. Apoptosis 23:532-553. https://doi.org/10.1007/s10495-018-1483-6 
17. Ghosh R, Guha D, Bhowmik S, Karmakar S (2013) Antioxidant enzymes and the mechanism of the bystander effect induced by ultraviolet C irradiation of A375 human melanoma cells. Mutat Res - Genet Toxicol Environ Mutagen 757:83-90. https://doi.org/10.1016/j.mrgentox.2013.06.022

18. Langelier M, Planck JL, Roy S, Pascal JM (2012) Structural Basis for DNA Damage-Dependent Poly(ADP-ribosyl)ation by Human PARP-1. $336: 728-732$. https://doi.org/10.1126/science.1216338

19. Berman HM, Westbrook J, Feng Z, Gilliland G, Bhat TN, Weissig H, Shindyalov IN PEB (2000) The Protein Data Bank. Nucleic Acids Res 28:235-242. https://doi.org/doi:10.1093/nar/28.1.235

20. Ramachandran GN, Ramakrishnan C, Sasisekharan V (1963) Stereochemistry of polypeptide chain configurations. J Mol Biol 7:95-99. https://doi.org/10.1016/S0022-2836(63)80023-6

21. Coste F, Malinge JM, Serre L, Shepard W, Roth M, Leng M, Zelwer C (1999) Crystal structure of a double-stranded DNA containing a cisplatin interstrand cross-link at 1.63 Å resolution: Hydration at the platinated site. Nucleic Acids Res 27:1837-1846. https://doi.org/10.1093/nar/27.8.1837

22. Yan Y, Zhang D, Zhou P, Li B, Huang SY (2017) HDOCK: A web server for protein-protein and protein-DNA/RNA docking based on a hybrid strategy. Nucleic Acids Res 45:W365-W373. https://doi.org/10.1093/nar/gkx407

23. Tuszynska I, Magnus M, Jonak K, Dawson W, Bujnicki JM (2015) NPDock: A web server for protein-nucleic acid docking. Nucleic Acids Res 43:W425W430. https://doi.org/10.1093/nar/gkv493

24. Schneidman-Duhovny D, Inbar Y, Nussinov R, Wolfson HJ (2005) PatchDock and SymmDock: Servers for rigid and symmetric docking. Nucleic Acids Res 33:363-367. https://doi.org/10.1093/nar/gki481

25. (2018) ACD/Chemsketch version 2018.1 Advanced Chemistry Development, Inc., Toronto, ON, Canada, www.acdlabs.com

26. The PyMOL Molecular Graphics System, Version 2.0 Schrödinger, DeLano LLC, W L (2002) Pymol An open-source Mol Graph tool CCP4 Newsl Protein Crystallogr 40:82-92

27. Discovery S Visualizer Software, version 2.5. http://www.accelrys.com

28. Macindoe G, Mavridis L, Venkatraman V, Devignes MD, Ritchie DW (2010) HexServer: An FFT-based protein docking server powered by graphics processors. Nucleic Acids Res 38:445-449. https://doi.org/10.1093/nar/gkq311

29. Mann M, Kumar S, Sharma A, Chauhan SS, Bhatla N, Kumar S, Bakhshi S, Gupta R, Kumar L (2019) PARP inhibition enhances cisplatin sensitivity in cervical cancer by modulating $\beta$-catenin signaling. Ann Oncol 30:v19. https://doi.org/10.1093/annonc/mdz238.065

30. Cheng H, Zhang Z, Borczuk A, Powell CA, Balajee AS, Lieberman HB, Halmos B (2013) PARP inhibition selectively increases sensitivity to cisplatin in ERCC1-low non-small cell lung cancer cells. Carcinogenesis 34:739-749. https://doi.org/10.1093/carcin/bgs393

31. Wang L, Liang C, Li F, Guan D, Wu X, Fu X, Lu A, Zhang G (2017) PARP1 in carcinomas and PARP1 inhibitors as antineoplastic drugs. Int J Mol Sci 18:116. https://doi.org/10.3390/ijms18102111

32. Zheng YD, Xu XQ, Peng F, Yu JZ, Wu H (2011) The poly(ADP-ribose) polymerase-1 inhibitor 3-aminobenzamide suppresses cell growth and migration, enhancing suppressive effects of cisplatin in osteosarcoma cells. Oncol Rep 25:1399-1405. https://doi.org/10.3892/or.2011.1212

33. Swindall AF, Stanley JA, Yang ES (2013) PARP-1: Friend or foe of DNA damage and repair in tumorigenesis. Cancers (Basel) 5:943-958. https://doi.org/10.3390/cancers5030943

34. Mitra A, Bhowmik S, Ghosh R (2021) Preferential interaction with c-MYC quadruplex DNA mediates the cytotoxic activity of a nitro-flavone derivative in A375 cells. J Photochem Photobiol 6:100033. https://doi.org/10.1016/j.jpap.2021.100033

35. Song L, McNeil EM, Ritchie AM, Astell KR, Gourley C, Melton DW (2017) Melanoma cells replicate through chemotherapy by reducing levels of key homologous recombination protein RAD51 and increasing expression of translesion synthesis DNA polymerase 3 . BMC Cancer 17:1-14. https://doi.org/10.1186/s12885-017-3864-6

36. Kauffmann A, Rosselli F, Lazar V, Winnepenninckx V, Mansuet-Lupo A, Dessen P, Van Den Oord JJ, Spatz A, Sarasin A (2008) High expression of DNA repair pathways is associated with metastasis in melanoma patients. Oncogene 27:565-573. https://doi.org/10.1038/sj.onc.1210700

37. Song L, Robson T, Doig T, Brenn T, Mathers M, Brown ER, Doherty V, Bartlett JMS, Anderson N, Melton DW (2013) DNA repair and replication proteins as prognostic markers in melanoma. Histopathology 62:343-350. https://doi.org/10.1111/j.1365-2559.2012.04362.x

38. Jewell R, Conway C, Mitra A, Randerson-Moor J, Lobo S, Nsengimana J, Harland M, Marples M, Edward S, Cook M, Powell B, Boon A, De Kort F, Parker KA, Cree IA, Barrett JH, Knowles MA, Bishop DT, Newton-Bishop J (2010) Patterns of expression of DNA repair genes and relapse from melanoma. Clin Cancer Res 16:5211-5221. https://doi.org/10.1158/1078-0432.CCR-10-1521

39. Malyuchenko NV, Kotova EY, Kulaeva OI, Kirpichnikov MP, Studitskiy VM (2015) PARP1 Inhibitors: Antitumor Drug Design. 7:27-37

40. Karam AK, Santiskulvong C, Fekete M, Zabih S, Eng C, Dorigo O (2010) Cisplatin and PI3kinase inhibition decrease invasion and migration of human ovarian carcinoma cells and regulate matrix-metalloproteinase expression. Cytoskeleton 67:535-544. https://doi.org/10.1002/cm.20465

41. Florea AM, Büsselberg D (2011) Cisplatin as an anti-tumor drug: Cellular mechanisms of activity, drug resistance and induced side effects. Cancers (Basel) 3:1351-1371. https://doi.org/10.3390/cancers3011351

42. Curtin NJ (2008) PARP Inhibitors and Cancer Therapy. Poly(ADP-Ribosyl)ation 218-233. https://doi.org/10.1007/0-387-36005-0_18

43. Kelley SK, Ashkenazi A (2004) Targeting death receptors in cancer with Apo2L/TRAIL. Curr Opin Pharmacol 4:333-339. https://doi.org/10.1016/j.coph.2004.02.006

44. Ghosh R, Girigoswami K, Guha D (2012) Suppression of apoptosis leads to cisplatin resistance in V79 cells subjected to chronic oxidative stress. Indian J Biochem Biophys 49:363-370 
Figures

A

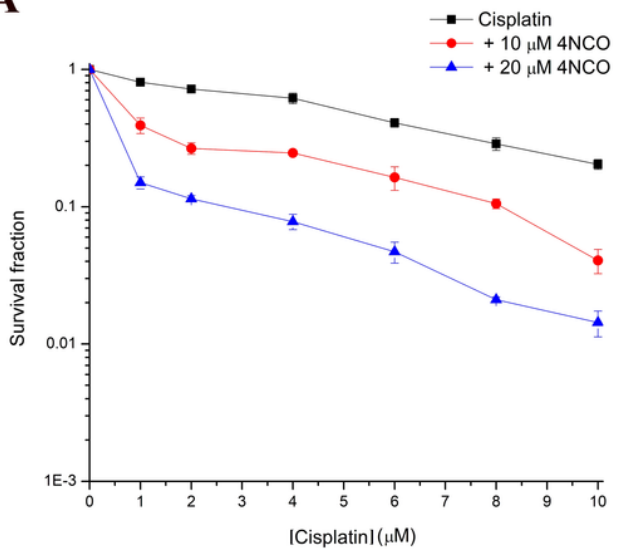

C

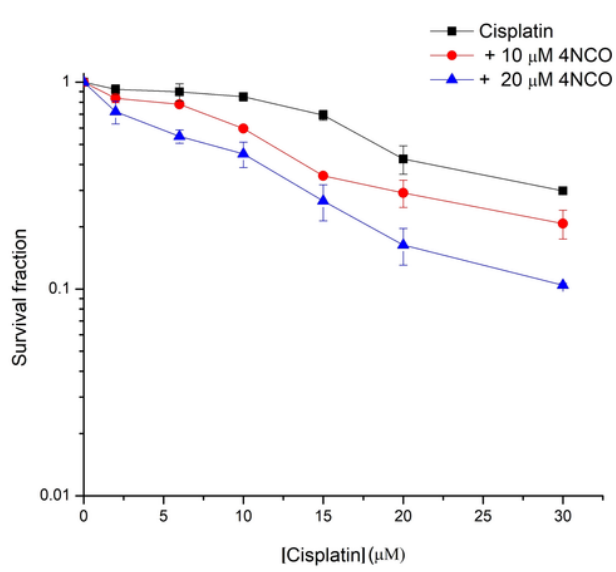

B

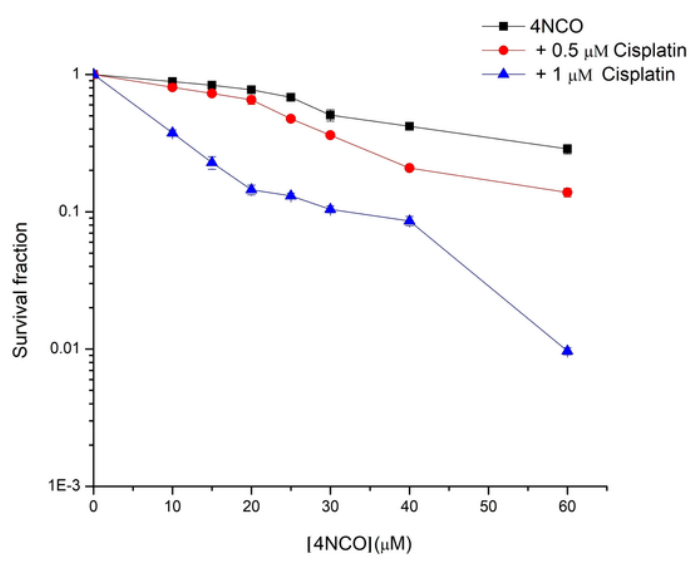

D

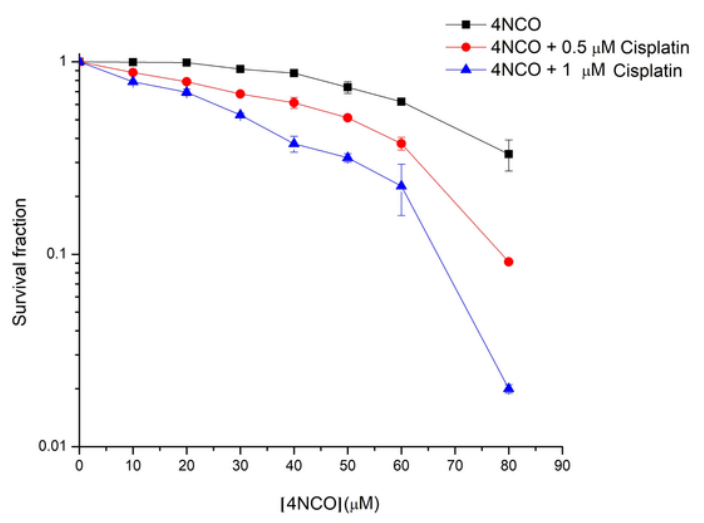

Figure 1

(A) Viability of exponentially grown $\mathrm{A} 375$ cells after treatment with different doses cisplatin $(0-10 \mu \mathrm{M})$ with or without co-treatment with $10 \mu \mathrm{M}$ or $20 \mu \mathrm{M}$ $4 \mathrm{NCO}(\mathrm{B})$ Viability of exponentially grown $\mathrm{A} 375$ cells after treatment with different doses $4 \mathrm{NCO}(0-60 \mu \mathrm{M})$ with or without co-treatment with $0.5 \mu \mathrm{M}$ or $1 \mu \mathrm{M}$ cisplatin (C) Viability of density inhibited quiescent A375 cells after treatment with different doses cisplatin $(0-30 \mu \mathrm{M})$ with or without co-treatment with $10 \mu \mathrm{M}$ or $20 \mu \mathrm{M} 4 \mathrm{NCO}$ (D) Viability of density inhibited quiescent A375 cells after treatment with different doses $4 \mathrm{NCO}(0-80 \mu \mathrm{M})$ with or without co-treatment with $0.5 \mu \mathrm{M}$ or $1 \mu \mathrm{M}$ cisplatin. The results shown are the mean \pm SD of three experiments 
A

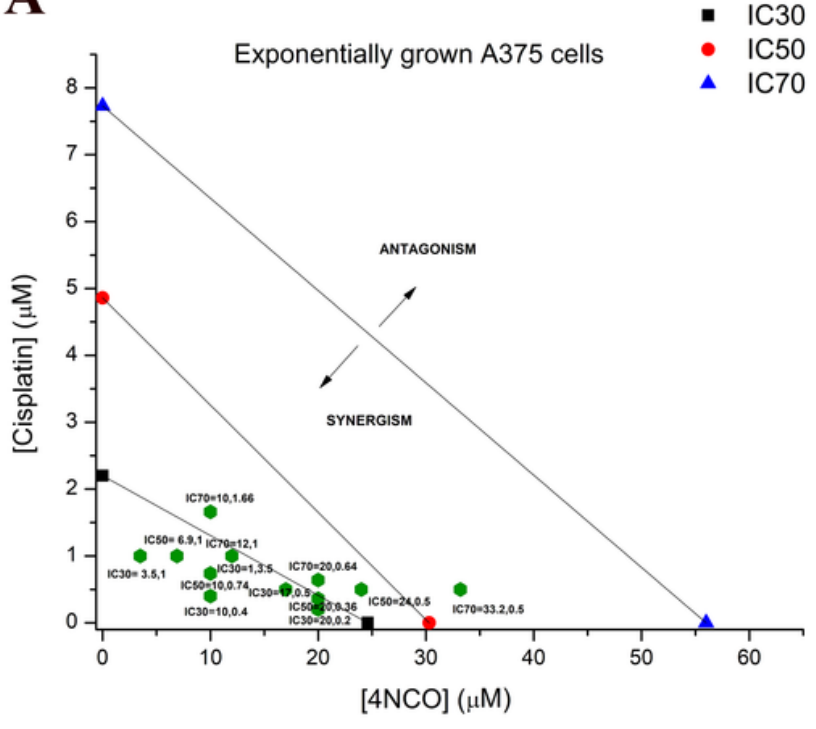

B

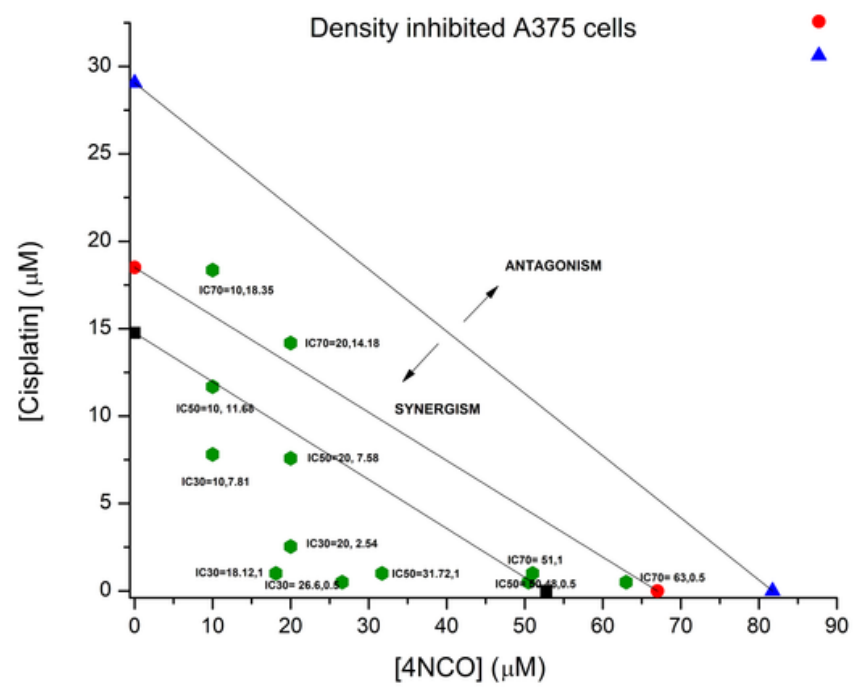

Figure 2

(A) Isobolograph indicating inhibitory concentration (IC) values of the combination of 4 NCO and cisplatin for exponentially grown A375 cells (B) Isobolograph indicating IC values of the combination of $4 \mathrm{NCO}$ and cisplatin for density inhibited A375 cells

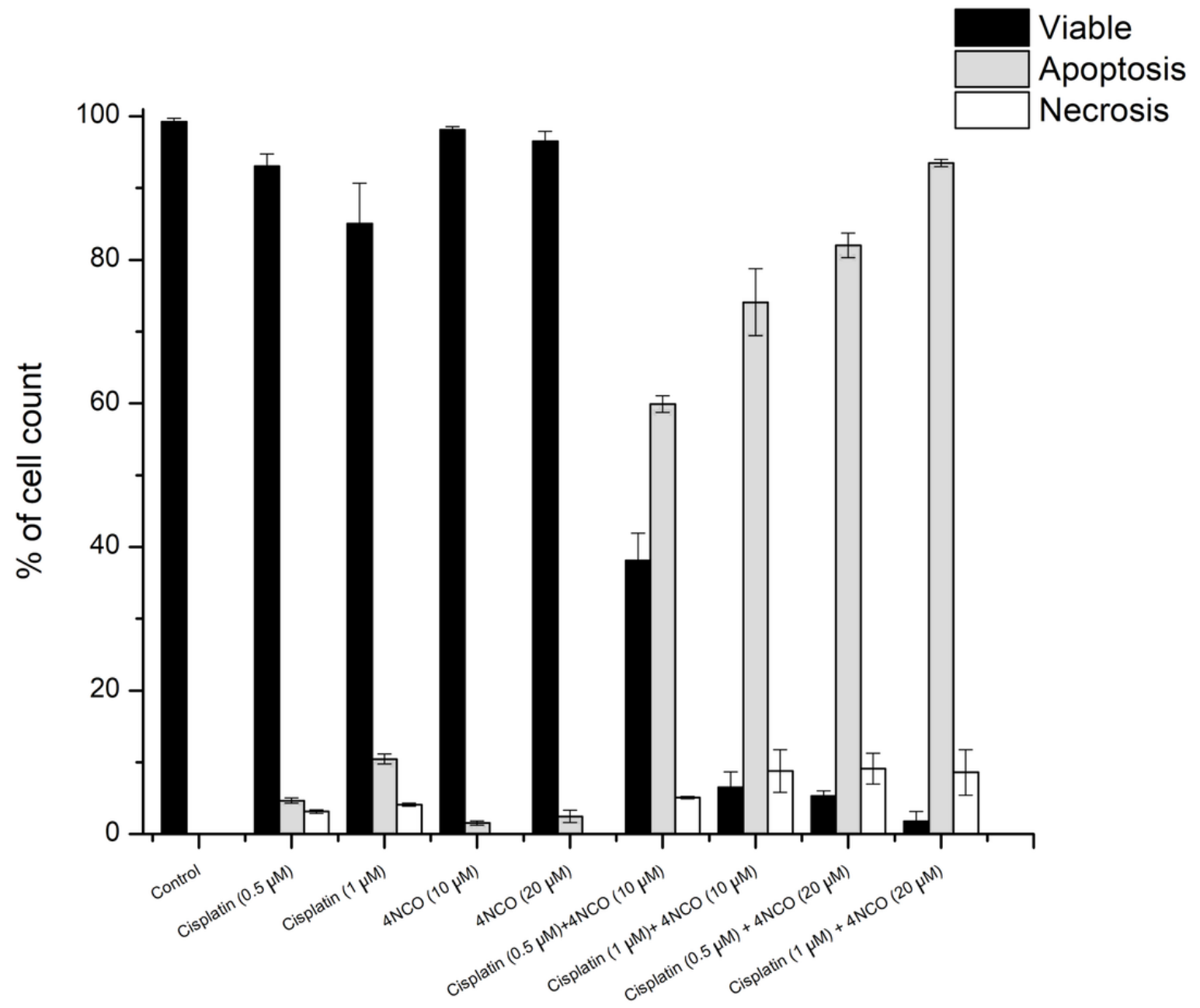

Figure 3 
Estimation of the proportion of viable, apoptotic and necrotic fraction of $\mathrm{A} 375$ cells on treatment with cisplatin $(0.5,1 \mu \mathrm{M})$ or $4 \mathrm{NCO}(10,20 \mu \mathrm{M})$ alone and in combinations for $24 \mathrm{hrs}$, as determined from LDH assay. The results shown are the mean \pm SD of three experiments

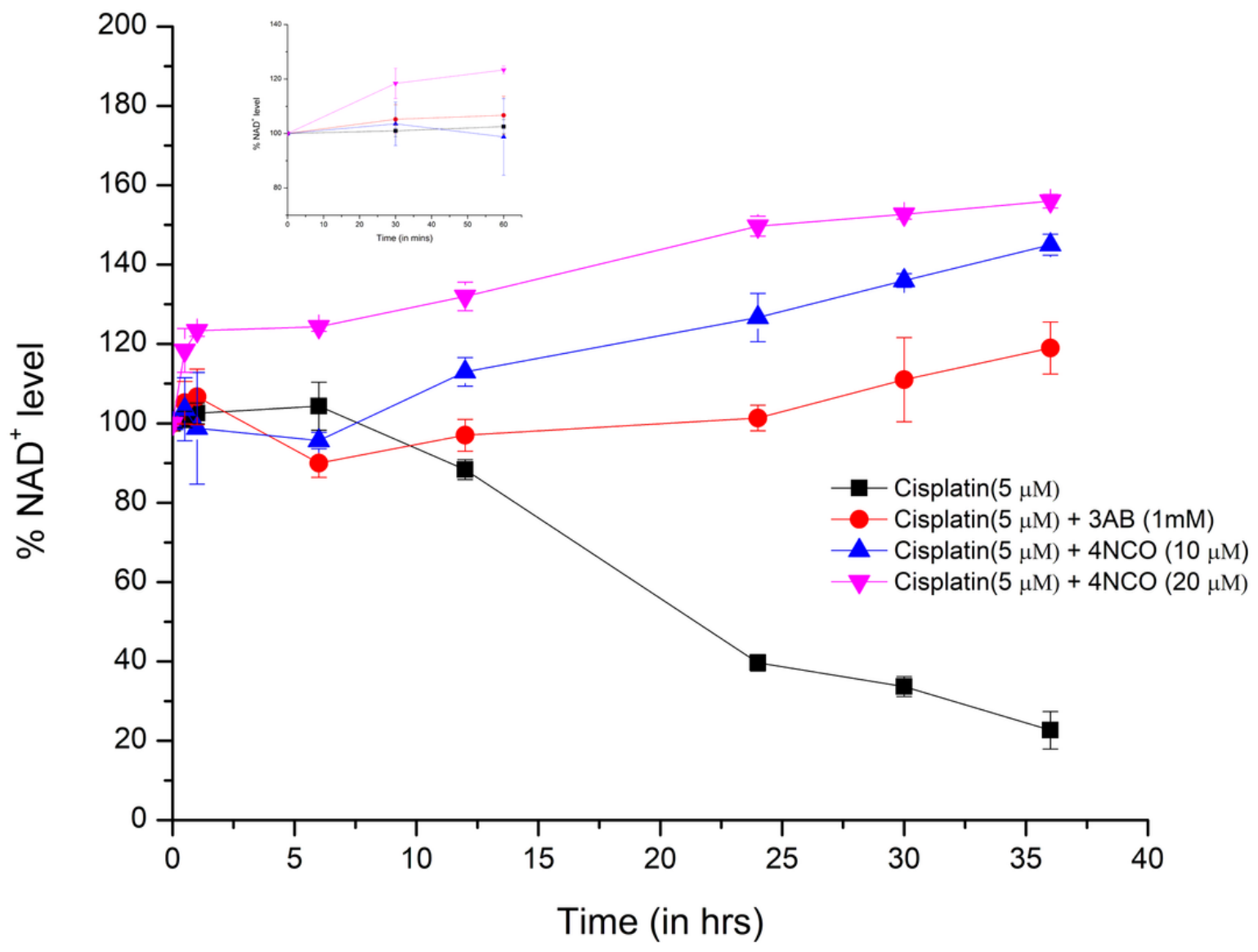

Figure 4

Effect of cisplatin alone $(5 \mu \mathrm{M})$ or in combination with $3 \mathrm{AB}(1 \mathrm{mM})$ or $4 \mathrm{NCO}(10,20 \mu \mathrm{M})$ on the intracellular NAD+ activity in A375 cells at different time periods after treatment. The results shown are the mean \pm SD of three experiments 
A

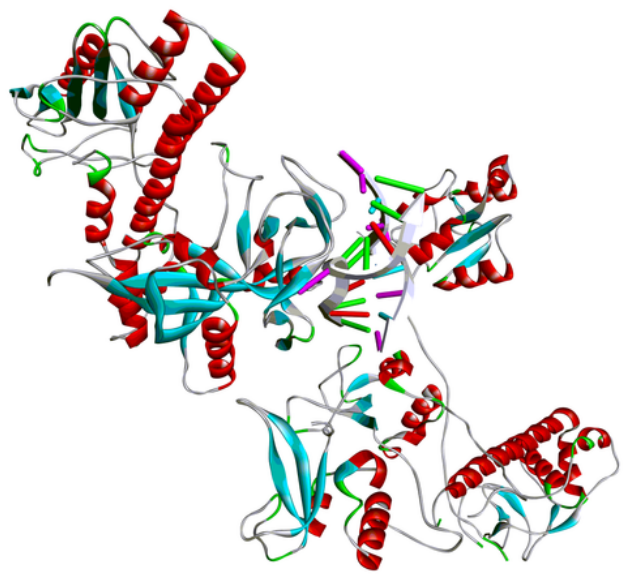

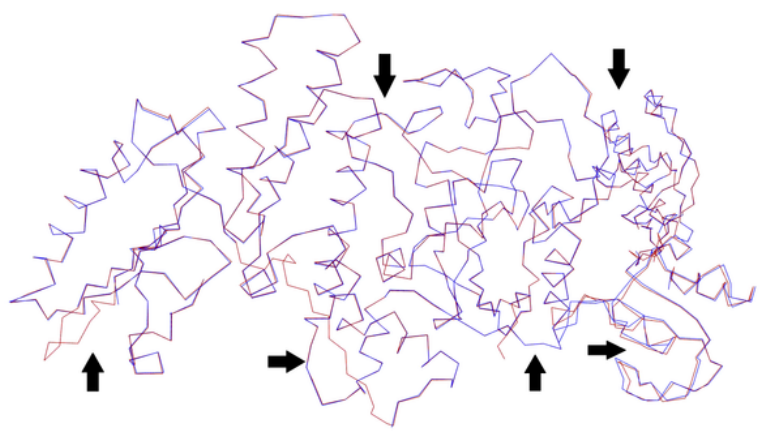

D

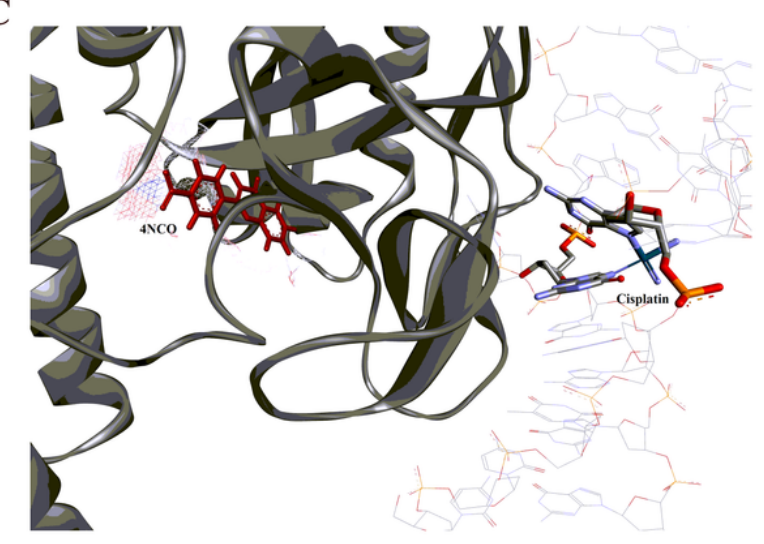

ALA
898

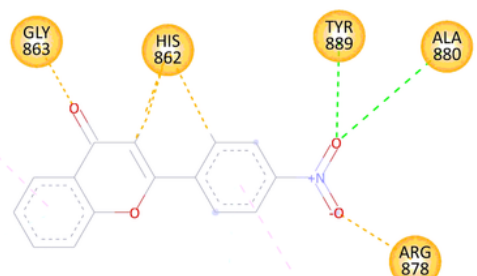

907

TYR
896

Figure 5

(A) Binding of DNA containing cisplatin-crosslinked adduct (PDB ID: 1A2E) with PARP1 (B) Superimposition of PARP1 before and after binding to cisplatincrosslinked DNA, arrows showing the positions having the major changes in the conformations (C) Binding of 4NCO to the modeled PARP1 - DNA complex containing cisplatin-crosslinked adduct (D) Hydrogen and hydrophobic interactions of 4NCO with the amino acid residues after binding to the modeled PARP1 - DNA complex containing cisplatin cross-linked adduct 